\title{
ACKNOWLEDGING, ASSESSING AND RECORDING GROUPED NON-TANGIBLE ASSETS IN THE BOOKS
}

\author{
Lecturer Ph.D. Manea Marinela-Daniela, marinelamanea7@yahoo.com \\ Ph.D. Student Gîju George Ciprian, ciprian_giju@yahoo.com \\ Valahia University of Târgoviste
}

\begin{abstract}
We cannot currently speak of development at a small or large scale without speaking of non-tangible assets. The famous marketing expert, Philip Kotler, recently ${ }^{l}$ stated in Bucharest that $80 \%$ of a company value lies in its non-tangible assets. However the latter are not in the books ${ }^{2}$. The success of some economies like the American, the Japanese, the German, the English, the French, the Swedish or the Dutch is a result of either the inventors' inventions which lay the basis for the development of some of the aforementioned countries or the entrepreneur spirit corroborated with making quality products and services.

Microsoft, Apple, IBM, Nokia, Phillips, Ford, Citroen, General Motors, Daimler Benz, Volvo or Coca Cola, Pepsi Cola, Nestle or Tutti Frutti, McDonald, KFC, they all represent successful brands worldwide acknowledged which were the origin of non-tangible assets under the form of patents, models and drawings, entrepreneur spirit, successful management, brands, licenses, franchises, quality of the employees, good commercial space/goodwill, etc.

Non-tangible assets have been and still are the scope of investigation for many research studies conducted to identify methods and techniques of quantifying the advantages they can represent for businesses. The present study is mainly meant to find, i.e. sort out, based on the information published by the international professional associations in the field - IVSC, IASB, IFAC - some working methods so as to set out the value of the non-tangible assets.
\end{abstract}

Introduction: The concept of non-tangible assets, also defined as intangible assets, is related to the necessity to assess, classifying in terms of accounting, immaterial elements such as those resulted from exclusive rights given by one-of-a-kind creations, namely patents, trademarks, models, industrial drawings, royalties, franchises, computer programs, etc, or by elements which turn into competition advantages on the market research and development, quality management, relations with suppliers and customers, organizational charts, goodwill, good locations for businesses, quality of the environment, reputation of an individual, a group or an organization, contracts, etc. A class of non-tangible assets which may play an important part in the business development is the grouped non-tangible assets also known as goodwill or commercial resources. It is usually rather difficult to acknowledge and assess the value of such assets. The assets falling under this class come to life and grow at the same time with the company they belong to. In terms of quantifying their measure, these assets represent the residual value of the assets we get after we subtract the non-tangible assets we can identify separately (i.e. patents, trademarks, royalties, franchises, licenses) of the total nontangible assets.

Grouped non-tangible assets are to be deemed:

- The customers attracted by the company's reputation by products and services with the best quality/price ratio or the goodwill created by the company;

\footnotetext{
${ }^{1}$ Philip Kotler in Bucharest on May 18 2005, the Conference at Sala Palatului: "How to create, win and master the market”

${ }^{2}$ Philip Kotler, “Marketing from A to Z”, Codecs Publishing House, 2004 Bucharest
} 
- The over profit listed for the identified assets; involved.

- The business value margin over the amount of the assets identified separately and

\section{1. Acknowledging the grouped non-tangible assets}

Over the decades, goodwill or commercial resources have become one of the most famous controversies in accounting. We cannot assess the commercial resources directly. Its value is generally set out by assessment which starts with the assessor's hypotheses. Consequently, we are subjective in setting out the value of the commercial resources.

The concept of acknowledging the goodwill in financial reports has found both supports and opponents amongst the professionals. The supporters of this concept state that this stands for the updated value of the exceeding income which a company can get. The actual value of this exceeding income is deemed to be similar to the determination of the updated value of cash flows combined with other assets and projects. The opponents of acknowledging the goodwill state that the price paid for the acquisition proves most of times to have started out with unrealistic expectations, implicitly leading to future reductions to zero in value of the goodwill.

Both trains of thought bear their credit. Many companies are able to get exceeding income from their investments. As a result, the price of the ordinary shares of these companies must have a share premium compared to the book value of the non-tangible assets. Consequently, the investors purchasing ordinary shares of such companies pay for the non-tangible assets (reputation, trademarks, etc).

There are companies getting reduced income from investments, despite some exceeding income indicated by a balance to the goodwill. The price of ordinary shares of such companies tends to go below the book value because their assets are over-assessed. Therefore, we must clearly understand that paying a price over the actual market value of the net asset of the company purchased is not enough to guarantee that the buying entity will continue to get exceeding income. We must thus make the difference between booking goodwill and economic goodwill. The economic goodwill relies on the entity's economic performance while the booking goodwill relies on accounting standards. The analysts and the investors will focus, when analyzing a company's financial reports, on the economic goodwill. Growing hand in hand with the company it relates to, the goodwill is the consequence of several factors ${ }^{3}$, such as:

- Human assets;

- The favorable environment built (the location, the surroundings);

- The economic environment.

The contribution of the human assets to setting out the value of a company can also be understood through the meaning of the Romanian saying: "Man consecrates the land". Therefore, a successful entrepreneur with real human qualities, a manager with administrative and organizational qualities, a specialist with scientific or technical qualities, a good professional doctor or an experienced sales agent can make a contribution in terms of the non-tangible assets to the activity they are involved with.

This is the reason which entitles us to speak of positive and negative aspects when associating the success of an activity with the people creating this success. The positive aspects are related to the fact that, beyond any doubt, the success of a company depends on such people. The negative ones refer to the non-tangible asset which cannot be transferred along with the company, unless the people making this company priceless decide to step in the transfer process. Take a successful dentist who acquired a reputation of a good specialist and who wants to step out and to sell his practice. The buyer, another dentist, will take over the practice, including the utensils, but, if

\footnotetext{
${ }^{3}$ Cristian Silviu Banacu, “Non-tangible assets, intellectual property”, Tribuna Economica Publishing House, Bucharest, 2005
} 
he has no expertise, he will lose the clients who, naturally, would guarantee the future of the business based on the reputation of the former.

The favorable environment built is another intangible element which can turn into what we call goodwill- a non-tangible asset of a company. Road crossings, being close to cultural, commercial, tourist, traffic objectives are, alone or along with the human assets, what we call goodwill, i.e. a place which helps the company grow through a large number of customers.

The natural environment, as non-tangible asset, can turn into non-tangible assets in case of tourist activities. Being close to seashores or mountains, being part of attractive sceneries, the quality of the environment proved by a low pollution level, can stand for non-tangible assets of some companies.

The stable economic environment, with a low inflation and a legislation favorable to economic growth can represent a beneficial factor for the development of economic activities in the area and recording of non-tangible assets within the companies residing in that area.

\subsection{Assessment of grouped non-tangible assets}

Assessment of non-tangible assets is generally conducted for numerous purposes, such as: acquisitions, sales, investments in new technologies or assets, mergers, etc. To this very end, the results of the assessment must:

- Assure an estimation of the value by use of credible, accurate, actual information and use of appropriate methods and techniques;

- Accurately identify and present the grouped non-tangible assets analyzed as well as the rights arising from owning them;

- Allow identification of an assessment basis and of the assessments used;

- Allow limitative hypotheses in assessing such grouped assets.

According to International Assessment Standards - IVSC - there are several approaches in assessing non-tangible assets. In terms of assessment, the approach means a way to estimate the value of a non-tangible asset using one or several methods. Choice of a specific approach and relating method is made depending on the nature of the non-tangible assets under assessment, as well as the sustainability and the nature of the income.

There are three approaches in assessing the non-tangible assets, as follows:

- Approach by market - also called the approach by comparison;

- Approach by income

- Approach by cost.

In assessing the goodwill, approaches based on costs and market comparisons are not so used; on the other hand, the approach by income with its three methods - the residual value method, the income capitalization method and the updated/daily cash flow method (DCF) - assure a coherent assessment of the grouped non-tangible assets.

The method of residual value sets out from the idea of taking goodwill out of non-tangible assets and quantifying its effect over the turnover and the profit.

The following formula can therefore be used ${ }^{4}$ :

$$
\mathrm{Vaf}=\mathrm{TaC}+\mathrm{TaN}+\mathrm{FRN}, \text { where (1) }
$$

Vaf - value of business,

TAC - total tangible assets used,

TaN - total non-tangible assets used,

FRN - net working capital.

\footnotetext{
${ }^{4}$ Cristian Silviu Banacu, “Non-tangible assets, intellectual property”, Tribuna Economica Publishing House, Bucharest, 2005
} 
To show the structure of the non-tangible assets used we can apply the following formula:

$$
\mathrm{TaN}=\mathrm{M}+\mathrm{B}+\mathrm{GW}+\mathrm{AC}+\mathrm{DA}+\mathrm{SW}, \text { where (2) }
$$

M - Trademarks,

B - Patents,

GW - goodwill, commercial resources,

$\mathrm{AC}-$ advantages arising from contracts,

DA - royalties,

SW - software.

Based on these two formulas - (1) and (2) - the goodwill is:

$$
\mathrm{GW}=\mathrm{TaN}-(\mathrm{B}+\mathrm{M}+\mathrm{AC}+\mathrm{DA}+\mathrm{SW})
$$

The income capitalization method implies conversion of future forecasted income (expected) into value, either by dividing the income, usually annual, by a capitalization rate, or by multiplying it by a multiplying coefficient (the reverse of the capitalization rate).

In applying this method we are to go through two stages:

$>$ Estimate the annual income;

$>$ Determine the capitalization rate.

The income is normally a net annual operating income obtained by subtracting the operational expenses of the gross income, and the capitalization rate is the ratio between the annual income and the selling price of the asset group. So, the basic formula for the income capitalization is:

Value $=$ Income/Capitalization rate or

Value $=$ Income $\mathrm{x}$ Multiplying coefficient (which is the reverse of the capitalization rate).

\section{The method of the daily cash flow (DCF)}

While the direct capitalization method implies use of current annual income as numerator (currently obtained), the DCF method tries to estimate the net annual income for a future predicting timeframe, based on current information. The DCF method means that the annual income is forecasted for a number of years (or months, quarters, semesters of future years). Subsequent to this, the periodical annual income forecasted will be converted into an updated value, by an updating rate applied to the yearly income of the timeframe forecasted (one, two, ... years).

The stages in applying the daily cash flow method are the following:

$>$ Estimate the income forecasted;

$>$ Determine the volume and the periodicity of the forecasted gross income;

$>$ Determine the volume and the periodicity of the expense associated with getting the gross income forecasted;

$>$ Subtract the annual operating expenses forecasted of the gross annual income forecasted;

$>$ Determine the updating rate;

$>$ Estimate the return value or the terminal value of the asset;

$>$ Calculate the updated value of the net annual cash flow and of the terminal value;

$>$ Calculate the appropriate value of the asset.

To assess the grouped mn-tangible assets we use the net cash flow to the disposal of the capital invested. In addition, the updating rate appropriate for the cash flow represents the rate of return requested by the investor to invest or maintain his capital invested, and the two potential capital suppliers are the own capital investor and the long-term creditor. 
Applying the DCF method based on the type of cash flow to the disposal of the capital invested will trigger off the value of the capital invested. This value is made up of three components:

- value of the tangible assets (land, buildings, machinery and equipment);

- value of the non-tangible assets (implicitly the grouped intangibles);

- net working capital.

As a consequence, to calculate the value of the grouped non-tangible assets only, we will have to subtract the other components of the capital invested (see above) of the capital invested itself.

\subsection{Recording grouped non-tangible assets in the books}

The International Accounting Standard IAS 38 "Intangible assets" focuses on assessing the non-tangible assets for the books, leading the way to the accounting approach and yield for the nontangible assets so as to complete other international accounting standards which make no express reference to this. Some definitions of this standard have been taken over by other assessing standards for non-tangible assets of IVSC (GN 4) or TEGoVA (GN 8), with a view to facilitate recording the value of non-tangible assets both in financial and accounting documents and in assessment reports.

IAS 38 refers to the fact that, when assessing the non-tangible assets, it is useful to take into account the environment elements where they occur, develop or are traded. The IAS 38 standard will thus be used along other standards, such as IAS 22 standard "Combinations of companies". Such an approach is extremely useful under circumstances such as:

Acquisitions of non-tangible assets deemed separately;

$>$ Acquisitions of non-tangible assets resulted from company buyouts, mergers, takeovers, joint-ventures;

$>$ Acquisitions of non-tangible assets based on government subsidies.

According to IAS 22 standard, acquisitions of non-tangible assets which are not included in special separate transfer contractual clauses will be quantified based on the cost assessed in relation to the actual value of the asset at the acquisition time. In case the non-tangible assets can be easily identified and separated and if they have a market, the actual value will rely on the market price which is either the current market price or the price resulted from a recent sale-buying of similar non-tangible assets. In case of non-tangible assets without a market, the value of the asset will reflect the amount the company would be willing to pay for its acquisition, based on the best information available resulted from similar transactions of non-tangible assets similar in terms of functions.

In addition, some grouped non-tangible assets can be acknowledged and recorded only in relation to a cash generating unit - the smallest group of identifying assets which, due to continuous use, can generate independent cash flows of other assets. This is the time when the issue of the assets value return occurs. Therefore, according to IFRS 3 - where there is a goodwill applicable to a minority interest within a cash generating unit, it will not be acknowledged in the consolidated financial reports of the parent company. 'Subsequently, should there be a minority interest within a cash generating unit to which the goodwill was assigned, the book value of that unit will comprise:

a) both the interest of the parent company and the minority interest in the unit's identifying net assets; and

b) the interest of the parent company in the goodwill".

As stated in paragraph 92, " with a view to test the depreciation of a cash generating unit which is not fully owned and which has a goodwill, the book value of that unit will be adjusted to the notional value prior to comparing it to the its returning value. This will be obtained by adding the goodwill owned by the minority to the book value of the goodwill assigned to the unit. This book 
value, notionally adjusted, will then be compared to the unit's returning value so as to set out whether the cash generating unit has been depreciated". Should the cash generating unit suffer a loss from the depreciation this loss will first be covered from the value of the goodwill assigned to the unit. "However, since the goodwill is acknowledged to the limit of the parent company's interest only, all and any losses from the depreciation relating to the goodwill shall be divided between the one assignable to the parent company and that assignable to minority interest, only the former being acknowledged as loss from goodwill depreciation".

\section{Example:}

At the beginning of tax year $\mathrm{N}$ company $\mathrm{M}$ purchases bonds in own capitals of company $\mathrm{T}$ in a percentage of 85 , for the amount of 45,000 units of measurement (=u.m.). At that time the identifying net assets of $\mathrm{T}$ have an actual value of 40,000 u.m., contingent debts being null. In the consolidated financial reports, $\mathrm{M}$ will acknowledge:

- A goodwill of 11,000 u.m. as difference between the acquisition cost of 45,000 u.m. and M's $85 \%$ interests in T's identifying net assets;

- T's identifying net assets at an actual value of 40,000 u.m.;

- A minority interest of 6,000 u.m. as a result of the interest of $15 \%$ of T's identifying net assets owned by shareholders other than $\mathrm{M}$.

Since T's assets considered together represent a small group of assets generating cash entries mostly independent of cash entries triggered off by other assets or groups of assets, $\mathrm{T}$ is deemed to be a cash generating unit which the goodwill resulted from the combination of companies can be assigned to. The existence of the goodwill which can be assigned to T's book value implies its testing in terms of depreciation, on annual basis or every time there are internal or external signals of value depreciation.

$\mathrm{M}$ uses the linear depreciation for a life expectancy of 10 years for T's identifying net assets, at the end of tax year $\mathrm{N}+1$ the returning value of the cash generating unit $\mathrm{T}$ being of 30,000 u.m.. As long as part of T's return value is assigned to the minority interests unacknowledged from the goodwill, T's book value, which according to paragraph 91 item a) and b) comprise, over and above the interest in the identifying net assets of both parent company and minorities, the interest of the parent company in the goodwill, will have to be adjusted to the notional value.

The notional value will include, over the elements stated at paragraph $91-51,000$ u.m., the value of the goodwill belonging to the minority interest of 1,941 u.m. (the goodwill assignable to M's $85 \%$ interest in $\mathrm{T}$ is 11,000 u.m.; therefore, the goodwill applicable to the minority interests of $15 \%$ at the acquisition date is $1,941 \mathrm{u}$.m.). The test to the depreciation, at the end of T's tax year $\mathrm{N}+1$, compares the notional value to its returning value as in the table below:

\begin{tabular}{|c|c|c|c|}
\hline N+1 tax yearend & $\begin{array}{c}\text { Identifying } \\
\text { assets }\end{array}$ & Goodwill & Total \\
\hline Gross book value & 40,000 & 11,000 & $51 ., 000$ \\
\hline Accumulated depreciation & $(8,000)$ & - & $(8,000)$ \\
\hline Book value & 32,000 & 11,000 & 43,000 \\
\hline $\begin{array}{c}\text { Unacknowledged minority } \\
\text { interests }\end{array}$ & - & 1,941 & 1,941 \\
\hline Notional value & 32,000 & 12,941 & 44,941 \\
\hline Return value & - & - & 30,000 \\
\hline Loss from depreciation & - & - & 14,941 \\
\hline
\end{tabular}

The loss from the depreciation of 14,491 um. will be first covered from the goodwill of 12,941 u.m., by reducing the latter to zero according to paragraph 104 , the difference being assigned to the unit's assets. However, since according to paragraph 93 only the part of the 
goodwill assigned to the parent company is acknowledged as loss from depreciation, the recording of the loss at the end of tax year $\mathrm{N}+1$ will be as follows:

\begin{tabular}{|c|c|c|c|}
\hline N+1 tax yearend & $\begin{array}{c}\text { Identifying } \\
\text { assets }\end{array}$ & Goodwill & Total \\
\hline Gross book value & 40,000 & 11,000 & 51,000 \\
\hline Accumulated depreciation & $(8,000)$ & - & $(8,000)$ \\
\hline Book value & 32,000 & 11,000 & 43,000 \\
\hline Loss from depreciation & 2,000 & $(11,000)$ & $(13,000)$ \\
\hline Value after assigning & 30,000 & - & 30,000 \\
\hline
\end{tabular}

A tricky issue is also deciding on the right time to conduct the depreciation tests. According to paragraph 96 of IAS 36 standard - "Depreciation of assets" "the annual depreciation test of a cash generating unit which was assigned the goodwill can be conducted at any time, inside one year, provided that the test is conducted at the same time every year. Different cash generating units (unit groups) can be tested in terms of depreciation at different times. However, if part of the goodwill assigned to one cash generating unit was purchased through a combination of companies during the current annual timeframe, that unit will be tested in terms of depreciation before the end of the current year".

The legislator admits that the depreciation test must be conducted in case of cash generating units to which we can allocate the goodwill at any time during the year, but consistently every year (at the same time every year), the mere reason being the cost reductions in applying the test. However, if the goodwill assigned to the cash generating unit is purchased as a result of a company combination inside the current year, the unit will be tested prior to closing the tax year.

The basis for the conclusions - 173, part of IAS 36 standard, admits that there are numerous situations when the books of those acquiring the value initially acknowledged subsequent to company combination exceeds the returning value, so that these are tempted to delay the recognition of a loss from depreciation until the end of the tax year following the company combination. This justifies the additional requirement included in the standard - testing the depreciation of that unit prior to closing the current period. "Should the assets forming the cash generating unit to which the goodwill was assigned to be tested for depreciation at the same time as the unit including the goodwill, they will be tested for depreciation before the unit including the goodwill. Similarly, should a cash generating unit forming a group of such units to which the good was assigned to be tested for depreciation at the same time as the group of units including the goodwill, the individual units will be tested for depreciation before the group of units including the goodwill."

\section{Conclusions:}

The issue of acknowledging and assessing the grouped non-tangible assets, as well as the return of their value implies a professional judgment and estimations inside the company, many times contested or placed under doubt, in terms of viability and accuracy. This is the reason why pertinent credible measurements, result of the partnership between accounting practitioners, assessors and company technicians, are required. 


\section{Bibliography}

Cristian Silviu Non-tangible assets, intellectual property, Tribuna Economica Banacu Publishing House, Bucharest, 2005

Iroval

Approaches in assessing the tangible assets, ANEVAR Library Collection, 2004

IASB

IAS 36 - Assets depreciation (revised in 2003)

PriceWaterhouseCoo

pers

Understanding IAS: Analysis and Interpretations of International Accounting Standards, $2^{\text {nd }}$ edition, 1999

Ristea M.

Company accounting methods and policies, Tribuna Economica Publishing House, Bucharest, 2000

Ristea M.

Company accounting options and methods, Tribuna Economica Publishing House, Bucharest, 2001

$* * *$

International Financial Reporting Standards - IFRS 2005, CECCAR Publishing House, 2005 